\title{
E-LEARNING BERBASIS MOODLE PADA PEMBELAJARAN IPA DI SEKOLAH
}

\author{
Sugiarti \\ Universitas PGRI Palembang
}

Citasi: Sugiarti. 2017. E-Learning Berbasis Moodle pada Pembelajaran IPA di Sekolah. Mangifera Edu Volume 2 Nomor 1, Juli 2017. Hal 43-49

\begin{abstract}
ABSTRAK
Tujuan penulisan artikel ini adalah untuk mengkaji pembelajaran e-learning berbasis moodle pada pembelajaran IPA di sekolah. Kemajuan teknologi informasi dan komunikasi berdampak besar terhadap segala bidang, termasuk pendidikan. Salah satu bentuk paradigma baru dalam sistem pendidikan adalah dalam bentuk e-learning. Media pembelajaran berbasis teknologi yang dapat dijadikan sebagai penunjang adalah dalam bentuk e-learning berbasis moodle pada pembelajaran IPA di sekolah. Siswa dapat belajar dari mana saja melakukan pencarian, penyelidikan, serta melakukan percobaan secara virtual melalui e-learning. E-learning berbasis moodle pada pembelajaran IPA di sekolah memungkinkan terjadinya interaksi pembelajaran dari mana dan kapan saja antar pengajar dan siswa. Serta dapat menjangkau peserta didikdalam cakupan yang luas, mempermudah penyempurnaan dan penyimpanan materi pembelajaran.
\end{abstract}

Kata Kunci: E-learning, Moodle, IPA

\section{PENDAHULUAN}

Pembelajaran IPA telah mengalami perkembangan seiring dengan perkembangan zaman dan kemajuan teknologi di era modernisasi saat ini. Melihat hal ini, perlu adanya suatu keahlian dalam penyusunan materi serta pengembangan aplikasi media pembelajaran IPA inovatif yang mendukung perubahan keadaan dan kebutuhan masyarakat. Menurut National Science Education Standard (1996, dalam Rustaman, 2005: 5) pengembangan professional bagi guru sains (IPA) perlu memadukan pengetahuan sains pembelajaran, pedagogi, dan siswa. Selain itu, pengembangan professional guru sains juga perlu mengaplikasikan pengetahuan ke dalam pengajaran sains melalui penyelidikan dan inkuiri. Seperti hasil penelitian Sugianto (2016:8), bahwa pendekatan jelajah alam sekitar pada konsep pertumbuhan dan perkembangantumbuhan dapat meningkatkan hasil belajar siswa. Oleh karena itu, perlu ada suatu perubahan dalam pembelajaransains.

Menurut Flick and Lederman (2006) teknologi dapat menjadi alat handal yang dapat membantu siswa untuk terlibat di dalam proses inkuiri. Teknologi juga dapat memudahkan 
siswa untuk membangun pemahaman konsep pengetahuan dan proses inkuiri untuk mempelajari IPA. Hal tersebut senada dengan pendapat Coffman (2009) bahwa, kegiatan inkuiri berbasis web adalah strategi yang baik untuk menggabungkan internet ke dalam kurikulum. Ini memberikan pedoman struktur dan spesifik untuk memastikan bahwa guru tetap fokus pada siswa belajar dan proses inkuiri untuk memahami konsep IPA. Pada saat yang sama, mengajarkan siswa keterampilan penyelidikan yang baik, seperti bertanya dan mencari informasi yang dibutuhkan untuk membuat keputusan. Salah satu alasan inkuiri berbasis web sangat bermanfaat adalah kesempatan bagi pertanyaan yangakan terjalin baik untuk standar peristiwa belajar dan kehidupan nyata, masalah, sumber informasi dan data.

Menurut Rusman (2012) memasuki abad ke-21 sekarang ini teknologi komputer sangat dirasakan kebutuhan dan kepentingannya untuk perbaikan dan peningkatan kualitas pembelajaran. Melalui pemanfaatan teknologi tersebut kita dapat meningkatkan kualitas SDM dan IPM, yaitu dengan cara membuka lebar- lebar terhadap akses ilmu pengetahuan dan penyelenggaraan pendidikan bermutu, terutama penerapan high tech dan high touch approach. Teknologi informasi berkembang sejalan dengan perkembangan teori dan komunikasi dan teknologi yang menunjang terhadap praktek kegiatan pembelajaran. Kegiatan pembelajaran merupakan kegiatan yang paling pokok dalam keseluruhan proses pendidikan. Hal ini berarti bahwa pencapaian tujuan pendidikan banyak bergantung kepada bagaimana proses pembelajaran dikemas dan dirancang secara tepat dan professional.

Moodle (Modular Object Oriented Dynamic Learning Environment) adalah software yang merupakan salah satu aplikasi dari konsep dan mekanisme belajar mengajar yang memanfaatkan teknologi informasi, yang dikenal dengan konsep e-learning. Moodle dapat digunakan secara bebas sebagai produk sumber terbuka (open source) di bawah lisensi General Public License dan dapat didownload secara gratis dari www.moodle.org. Aplikasi Moodle dikembangkan pertama kali oleh Martin Dougiamas pada Agustus 2002 dengan Moodle Versi 1.0 dan merupakan program open source yang paling terkenal di antara program- program e-learning yang ada (Amiroh, 2012).

The idea of web-based virtual laboratories is not new (Hoffman, 1994; Potter,1996; Preis, 1997 dalam Tejedor, Martinez and Vidaurre, 2008). Salah satu solusi yang dapat membantu siswa dalam mengembangkan keterampilan berpikir kompleks adalah melalui visualisasi konsep-konsep fisika yang dikemas dalam bentuk multimedia interaktif yang dapat disajikan secara offline ataupun online menggunakan teknologi internet. Secara umum manfaat yang dapat diperoleh dari penggunaan multimedia interaktif pada 
pembelajaran di antaranya adalah proses pembelajaran dapat berjalan lebih menarik, lebih interaktif, jumlah waktu mengajar dapat dikurangi, proses belajar mengajar dapat dilakukan di mana dan kapan saja, serta kualitas belajar siswa dapat ditingkatkan (Heinich, 1996).

Telah banyak hasil penelitian terdahulu yang menunjukkan bahwa efektivitas pembelajaran menggunakan sistem e-learning efektif diterapkan pada pembelajaran IPA (Sugiarti, 2014; Nuriyanti, 2013). Siswa dapat mengakses materi pembelajaran kapan saja dan dari mana saja, selain itu materi dapat dapat diperkaya dari berbagai sumber belajar termasuk multimedia dapat diperbaharui oleh pengajar. Pengajar dapat mengembangkan media pembelajaran menjadi lebih menarik dan relevan serta dapat memudahkan siswa belajar secara mandiri.

\section{PEMBAHASAN}

\section{Hakikat E-Learning}

E-learning terdiri dari huruf $e$ yang merupakan singkatan dari electronic dan learning yang berarti pembelajaran. Dengan demikin, e-learning bisa diartikan sebagai pembelajaran dengan memanfaatkan bantuan perangkat elektronik. Secara terminologi, $e$ learning adalah proses pembelajaran yang dilakukan melalui network (jaringan komputer), biasanya lewat internet atau intranet.

Dalam salah satu publikasinya di situs about e-learning.com, (dalam Rusman, 2012: 291), Himpunan Masyarakat Amerika Serikat untuk Kegiatan Pelatihan dan Pengembangan (The American Societyfor Training and Develovment/ ASTD) (2009) mengemukakan definisi e-learning sebagai berikut: " $E$ learning is a broad set of applications and process which include web-based learning, computer-based learning, virtual and digital classromes. Much of this is delivered via the internet, intranets, audio ad videotape, satellite broadcast, interactive TV, and CD-ROM. The definition of e-learning varies depending on the organization and how it is used but basically it is involves electronic means communication, education and training."

Definisi tersebut menyatakan bahwa e-learning merupakan proses dan penerapan pembelajaran berbasis web (web-based learning) pembelajaran berbasis komputer (computer based learning), kelas virtual (virtual classrooms) dan/atau kelas digital (digital classrooms). Materi-materi dalam kegiatan pembelajaran elektronik tersebut kebanyakan dihantarkan melalui media internet, tape video atau audio, penyiaran melalui satelit, televisi interaktif serta CD - ROM. 
Menurut Elliot Masie, Cisco and Cornellia (dalam Munir, 2009: 167) menjelaskan e-learning adalah pembelajaran dimana bahan pembelajaran disampaikan melalui media elektronik seperti internet, satelit, tv, CD-ROM, dan lain-lain jadi tidak harus internet, karena internet merupakan salah satu bagian darie-learning.

Sementara itu, definisi e-learning berikut menitikberatkan pada pengalaman belajar dan sumber belajar. Menurut Horton, 2006: 5, e-learning is the use of information and computer technologies to create learning experiences. Sedangkan, Holmes dan Gardner 2006;14, merumuskan lebih sederhana yakni, elearning: online access to learning resources, anytime, anywhere learning experiences. Menurut mereka, penyediaan sumber belajar dan menciptakan pengalaman belajar menjadi aspek terpenting dalam penyelenggaraan e-learning. Fokus kedua definisi tetap, yaitu proses belajar. Pengalaman belajar seperti berlatih dalam suatu laboratorium maya, memecahkan masalah bersama tim dalam dunia maya, sebaiknya dikembangkan dengan mengacu kepada teori belajar dan pembelajaran. Holmes dan Gardner menyebutkan bahwa prinsip belajar kontruktivistik penting dalam menciptakan sumber belajar maya. Asumsi seseorang yang mengikuti $e$ learning, adalah ia sedang melalui proses belajar mandiri. Horton menegaskan peranan bagaimana media digital diberdayakan dengan maksimal ditinjau dari desain pembelajaran, teori belajar, dan desain pesan agar dapat menghasilkan pengalaman belajar yang baik bagi pesertadidik.

Dari definisi tersebut dapat disimpulkan bahwa e-learning berarti pembelajaran yang memanfaatkan teknologi informasi dan komunikasi. E- learning merupakan proses belajar secara efektif yang terdiri dari dukungan dan layanan dalam belajar yang disampaikan melalui media elektronik.

\section{Pembelajaran E- Learning Berbasis Moodle}

Moodle adalah paket perangkat lunak yang diproduksi untuk kegiatan belajar berbasis internet dan situs yang menggunakan prinsip social constructionist pedagogy. Moodle merupakan singkatan dari Modular Object Oriented Dynamic Learning Environment yang berarti tempat belajar dinamis dengan menggunakan model berorientasi objek atau merupakan paket lingkungan pendidikan berbasis web yang dinamis dan dikembangkan dengan konsep berorientasi objek (Rice and Smith, 2010).

Moodle merupakan salah satu aplikasi dari konsep dan mekanisme belajar mengajar yang memanfaatkan teknologi informasi, yang dikenal dengan konsep e- learning,dan 
merupakan program open source yang paling terkenal di antara program-program $e$ learning yang ada. Moodle dapat digunakan secara bebas sebagai produk sumber terbuka (open source) di bawah lisensi General Public License dan dapat didownload secara gratis dari www.moodle.org. Aplikasi Moodle dikembangkan pertama kali oleh Martin Dougiamas pada Agustus 2002 dengan Moodle Versi 1.0. (Amiroh, 2012).

Gb. 1 : e-learning menggunakan aplikasi moodle

Sumber: http://202.154.56.82/moodle/course/category.

Gambar diatas adalah contoh e-learning menggunakan aplikasi moodle yang dikembangkan pada mata pelajaran IPA. Moodle dapat digunakan untuk membangun sistem dengan konsep e-learning (pembelajaran secara elektronik). Berbagai bentuk materi pembelajaran dapat dimasukkan dalam aplikasi moodle ini. Berbagai sumber dapat ditempelkan sebagai materi pembelajaran. Naskah tulisan yang ditulis dari aplikasi pengolah Microsoft word, materi persentasi yang berasal dari Microsoft Power Point, Animasi Flash, percobaan virtual seperti PhET dan bahkan materi dalam format audio dan video dapat ditempelkan sebagai materi pembelajaran, sehingga dapat memudahkan siswa untuk melakukan proses inkuiri seperti, mencari informasi, melakukan percobaan, mengumpulkan data, serta berlatih untuk menyelesaikan soal pada link yang telah ditautkan pada aplikasimoodle.

Berikut ini beberapa aktivitas pembelajaran yang didukung oleh moodle menurut Lee Stocker (2011) adalah sebagai berikut:

1) Assignment: Fasilitas ini digunakan untuk memberikan penugasan kepada peserta pembelajaran secara online. Peserta pembelajaran dapat mengakses materi tugas dan mengumpulkan hasil tugas mereka dengan mengirimkan file hasil pekerjaan mereka. 
2) Forum \& chat: Sebuah forum diskusi secara online dapat diciptakan dalam membahas suatu materi pembelajaran. Antara pengajar dan peserta pembelajaran dapat membahas topik-topik belajar dalam suatu forumdiskusi.

3) Kuis: Dengan fasilitas ini memungkinkan untuk dilakukan ujian ataupun test secara online.

4) Database Activity: Dengan aktifitas ini, guru dan/atau siswa dapat membuat, melihat dan mencari bank data mengenai topikapapun.

5) Glossary: Pada aktivitas ini, pererta dapat membuat kumpulan/daftar pengertian pengertian kata, sepertikamus.

6) Link to Files or web pages: Dengan resource ini, guru dapat membuat link ke halaman web ataupun file lain yang ada diinternet.

Ketika teknologi dipergunakan sebagai satu alat untuk meningkatkan proses kegiatan belajar ini akan menjadi sebuah teknologi belajar. Teknologi dapat menjadi alat yang dapat membantu guru untuk mengembangkan proses penyelidikan ilmiah dan mengajarkannya pada siswa. Pengajar dapat membantu mentransformasikan kelas sains ke dalam satu lingkungan belajar dimana murid dengan aktif membangun pengetahuan. Teknologi dapat menjadi alat handal yang dapat membantu siswa untuk terlibat di dalam proses kegiatan ilmiah untuk mempelajari IPA.

\section{KESIMPULAN}

Pembelajaran e-learning berarti pembelajaran yang memanfaatkan teknologi informasi dan komunikasi. E-learning berbasis moodle pada pembelajaran IPA di sekolah memungkinkan terjadinya interaksi pembelajaran dari mana dan kapan saja. Serta dapat menjangkau peserta didik dalam cakupan yang luas, Mempermudah penyempurnaan dan penyimpanan materi pembelajaran. Fasilitas yang tersedia dalam teknologi internet dan berbagai perangkat lunak (software) yang terus berkembang turut membantu mempermudah pengembangan bahan belajar elektronik. Demikian juga dengan penyempurnaan atau pemutakhiran bahan belajar sesuai dengan tuntutan perkembangan materi keilmuannya dapat dilakukan secara periodik dan mudah. Di samping itu, penyempurnaan metode penyajian materi pembelajaran dapat pula dilakukan, baik yang didasarkan atas umpan balik dari peserta didik maupun atas hasil penilaian guru selaku penanggung jawab atau pembina materi pembelajaran itu sendiri. 


\section{DAFTAR PUSTAKA}

Amiroh. 2012. Kupas Tuntas Membangun E-Learning dengan Learning Management System Moodle. Sidoarjo: Genta Group Production.

Coffman, Teresa. 2009. Engaging Students Through Inquiry- Oriented Learning and Technology. United. Kingdom.

Flick, L.B and Lederman, N.G. 2006. Scientific Inquiry and Nature of Science. USA: Kluwer Academic Publisher. 